DOI 10.18551/rjoas.2019-01.15

\title{
SUCCESSION PROCESS IN FAMILY BUSINESS: A STUDY ON THE MANUFACTURE OF RICE MILL IN ACEH BESAR DISTRICT
}

\author{
Isnaniati* \\ Graduate Study Program of Agribusiness, Syiah Kuala University, Banda Aceh, Indonesia
}

Fajri, Nugroho Agus

Faculty of Agriculture, Syiah Kuala University, Banda Aceh, Indonesia

*E-mail: isnaniati@gmail.com

\begin{abstract}
Agricultural sector companies in Aceh especially in Aceh Besar are owned by families, one of which is a company in the field of rice milling industry. The company has an important role to meet the needs of food and employment. So for the family business should be successful and long-lived. One way is by preparing a successor through the succession process. The succession process can be carried through; (1) determination of the criteria for a successor (2) the development potential successor, (3) the involvement of potential successor in the family business. The design of the study is a qualitative method, therefore the results in this study cannot be generalized for other family businesses. $92.27 \%$ of candidates for successor have criteria acceptable, charismatic, energic, managing, achieving and networking, $69.44 \%$ or most of family business leaders develop a candidate of successor and $75 \%$ or most of prospective successors are involved in every business activity. The results in this study indicate that the successor is ready to replace the founder or manager as a family business leader.
\end{abstract}

\section{KEY WORDS}

Agricultural sector companies, rice milling industry, family business, succession, succession process.

In terms of succession planning, Price Waterhouse Cooper survey results of 2014 mentions the family business in Indonesia is better than the world average. Although only $27 \%$ had a successor plan structured and documented efforts, it has been better than the world average as a whole (16\%). More than $50 \%$ of family businesses in Indonesia plan to pass on ownership to the next generation but still appoint professionals to sit in the management structure. And only $25 \%$ of Indonesia's family businesses will give up ownership and management to the next generation.

Agricultural sector companies in Aceh especially in Aceh Besar are owned by families, one of which is a company in the field of rice milling industry. This company has an important role to fulfill food needs and employment. So for the family business should be successful and long-lived. One way is to make preparations for successors. Through the succession process. The succession process can be carried through; (1) determination of the criteria for a successor (2) the development potential successor, (3) the involvement of potential successor in the family business.

\section{LITERATURE REVIEW}

Family and business are two different things. The family as a system is more emotional because united by bonds that influence in business. Business as systems based on job market-oriented and take the opportunity of any changes. With each of these characteristics, it is not easy to combine these two systems into a harmonious and profitable alloy (Susanto, 2005). 
Family company is a phenomenon in the business world. In addition to numerous, the company has contributed to the family income countries (Susanto, 2005). A successful family company is a company that is able to accommodate changing times. Each generation is brave and successfully adapts new ideas that are developing. But this can be a conflictprone and failure area. The older generation may be reluctant or late to give way or give a little confidence to new ideas from the younger generation (Gordon and Nicholson, 2008).

Many first-generation family company successfully through the early development stages of the business life to grow and to develop flexible with high diligence effort in a turbulent environment. The ability to maintain a balance between flexibility and control is generally not owned by the second generation or the next generation, because families of the next generation are usually not involved in the struggle to maintain the survival of the company by their parents (Hartanto, 2009).

Family businesses face major threats that the threat from within: succession management. The founder of the family business must plan for succession before they retire (Zimmerer and Scarborough, 2008). Family business has a philosophy that is respecting the early generation (founders) in terms of the decision to give a baton to the choosen generation (Tjondrorahardja, 2004).

Succession in family company in a strategic position, especially in maintaining the viability of the company. Not many family companies can survive until the third generation and so on, it requires careful succession planning. The success of the succession has a relationship with the family company performance (Wahjono, 2009).

In general, the succession step consists of three stages; 1). Transferring knowledge and networking and develop the right attitude; 2). Transferring charisma and began utilizing owned networks; 3). Develop skills, charisma and reputation. Effective succession in the family company is to plan for succession as early as possible by involving family members and provide options for the next generation to join or not within the company (Susilo, 2006).

To preserve the continuity of the company, it need to be planned succession process, so that the process can run well, it is necessary to follow some succession planning (Soegoto, 2009):

1. Provide sufficient time or initiate early succession process;

2. Using a family business consultant to create a succession plan that estimates the value of the company;

3. Evaluate the feasibility of the beneficiaries of succession;

4. Ensure successors have the skills and motivation to continue doing business;

5. Provide a transition period for a potential successor to learn the business;

6. Consider the employee stock option plans (ESOP) for management succession;

7. Establish and keep dates for completion of the transition.

\section{METHODS OF RESEARCH}

The study was conducted in Darussalam and Kuta Baro sub-district in Aceh Besar District. The study was conducted by census method, in the rice milling industry. Of the total 24 rice milling companies, two of which were not family businesses, and 7 family businesses refused to be used as subjects in this study, so the total research subjects were 15 family businesses. But in the research process of 15 family companies, only 8 family companies have had a successor to the family business. The number of family business successors as much as 12 potential successor.

The design of study is qualitative method and data collection in this study by conducting interviews with the owners of the family business, a list of questions for the interview had been developed previously, the authors also have a short conversation. The findings in this study were discussed descriptively, therefore the results in this study cannot be generalized for other family businesses.

Data processing is done by calculating the percentage of the number of answers given by respondents, and then drawing conclusions based on the number of percentages obtained based on: 
Determine Range $(R)$ :

$$
R=\text { Biggest data }- \text { Smallest data }=100-0=100
$$

Determine how many classes to be made $(K)$ :

$$
\begin{gathered}
K=1+3.33 \log N \\
K=1+3.33 \log 12=4.59=4
\end{gathered}
$$

Where: $\mathrm{K}=\mathrm{a}$ lot of classes that will be made $\mathrm{N}=$ number of data or potential successor.

Determine the interval length of the class (I):

$$
\mathrm{I}=\mathrm{R} / \mathrm{K}=100 / 4=25
$$

Where: $\mathrm{I}=$ Interval class; $\mathrm{R}=$ Range; $\mathrm{K}=$ Many classes will be made.

Based on these calculations, then the criteria for evaluating the stages of the succession process carried out by successor's candidate are:

$$
\begin{gathered}
100 \%=\text { all of them } \\
76 \%-99.99 \%=\text { almost all } \\
51 \%-75 \%=\text { mostly } \\
26 \%-50 \%=\text { fraction } \\
1 \%-25 \%=\text { at least } \\
0=\text { no one }
\end{gathered}
$$

Draw conclusions based on the number of scores obtained at each stage of the succession process:

$$
K=1+3.33 \log N
$$

Where: $N=$ number of stages of the succession process; $K=1+3.33 \log 3=2.58=2$; $\mathrm{I}=100 / 2=50$.

Based on these calculations, it can be concluded that the succession process carried out in the family business are: $a . \leq 50 \%$ means the prospective successor is not ready to replace the founder or manager as the family business leader; $b$. $>50 \%$ means the candidate for successor is ready to replace the founder or manager as the family business leader.

\section{RESULTS AND DISCUSSION}

Characteristics of Family Business of the Rice Mill Industry in Aceh Besar. Almost all the family businesses of the rice milling industry were managed by men. However, in this study there was one company managed by women. This thing shows that if given the opportunity or trust, women are also able to manage and become family business leaders. Although for the rice mill industry sector men are more prioritized to become business leaders.

Characteristics of family business of rice milling industry in Aceh Besar differentiated by category of business, years of existence, the old business, the use of the workforce, the production of rice and net income. There are three scales of business in the rice milling industry; (1) small or rice production $0.1-0.3$ tons / hour (2) medium or rice production 0.3-0.7 tons / hour and (3) large or rice production> 7 tons / hour.

Succession process. The succession process in this study consists of three stages, namely (1) determining the criteria for candidate successors (2) developing prospective successors, (3) the involvement of potential successors in the family business. 
Determination of criteria for prospective successors. Susanto (2005) states that prospective successors must have ACE MAN criteria or acceptable, charismatic, energic, managing, achieving and networking.

Table 1 - Determination of criteria for prospective family business successors

\begin{tabular}{|c|c|c|c|c|c|c|c|c|c|c|c|c|}
\hline \multirow{2}{*}{ Criteria } & \multicolumn{12}{|c|}{ Successors Candidate } \\
\hline & 1 & 2 & 3 & 4 & 5 & 6 & 7 & 8 & 9 & 10 & 11 & 12 \\
\hline Acceptable & $\checkmark$ & $\checkmark$ & $\checkmark$ & $\checkmark$ & $\checkmark$ & $\checkmark$ & $\checkmark$ & $\checkmark$ & $\checkmark$ & $\checkmark$ & $\checkmark$ & $\checkmark$ \\
\hline Charismatic & $\checkmark$ & $\checkmark$ & $\checkmark$ & $\checkmark$ & $\checkmark$ & $\checkmark$ & $\checkmark$ & $\checkmark$ & $\checkmark$ & $\mathrm{X}$ & $\mathrm{X}$ & $\checkmark$ \\
\hline Energic & $\checkmark$ & $\checkmark$ & $\checkmark$ & $\checkmark$ & $\checkmark$ & $\checkmark$ & $\checkmark$ & $\mathrm{X}$ & $\checkmark$ & $\mathrm{X}$ & $\mathrm{X}$ & $\checkmark$ \\
\hline Managing & $\checkmark$ & $\checkmark$ & $\checkmark$ & $\checkmark$ & $\checkmark$ & $\checkmark$ & $\checkmark$ & $\checkmark$ & $\checkmark$ & $\checkmark$ & $\mathrm{X}$ & $\checkmark$ \\
\hline Achieving & $\checkmark$ & $\checkmark$ & $\checkmark$ & $\checkmark$ & $\checkmark$ & $\checkmark$ & $\checkmark$ & $\checkmark$ & $\checkmark$ & $\checkmark$ & $\checkmark$ & $\checkmark$ \\
\hline Networking & $\checkmark$ & $\checkmark$ & $\checkmark$ & $\checkmark$ & $\checkmark$ & $\checkmark$ & $\checkmark$ & $\checkmark$ & $\checkmark$ & $\checkmark$ & $X$ & $\checkmark$ \\
\hline Percentage & $100 \%$ & $100 \%$ & $100 \%$ & $100 \%$ & $100 \%$ & $100 \%$ & $100 \%$ & $83,33 \%$ & $100 \%$ & $66,67 \%$ & $33,33 \%$ & $100 \%$ \\
\hline Average & $90,27 \%$ & & & & & & & & & & & \\
\hline
\end{tabular}

Source; primary data processed (2018).

In order to determine a successor candidate criteria, almost all potential successor or $90.27 \%$ have acceptable criteria, charismatic, energetic, managing, Achieving dam networking. On the acceptable criteria, all potential successors are able to accept criticism directed at them regarding family business management. They all also able to listen to the opinions both from the family and from business partners (customers and suppliers of raw materials). The criticism given by ordinary families regarding (1) customer service (2) maintaining product quality or quality.

Development of potential successors. The development of candidate successors is carried out through three stages, namely; (1) education, (2) transfer of knowledge, and (3) an experience outside of the family company.

Table 2 - Development of successors

\begin{tabular}{|c|c|c|c|c|c|c|c|c|c|c|c|c|}
\hline \multirow[t]{2}{*}{ Development Activities } & \multicolumn{12}{|c|}{ Successors Candidate } \\
\hline & 1 & 2 & 3 & 4 & 5 & 6 & 7 & 8 & 9 & 10 & 11 & 12 \\
\hline Education & $\checkmark$ & $\checkmark$ & $\checkmark$ & $\checkmark$ & $\checkmark$ & $\checkmark$ & $\checkmark$ & $\checkmark$ & $\checkmark$ & $\checkmark$ & $\checkmark$ & $\checkmark$ \\
\hline Transfer of knowledge & $\checkmark$ & $\checkmark$ & $\checkmark$ & $\checkmark$ & $\checkmark$ & $\checkmark$ & $\checkmark$ & $\checkmark$ & $\checkmark$ & $\checkmark$ & $\checkmark$ & $\checkmark$ \\
\hline An experience outside of the family business & $\mathrm{X}$ & $\mathrm{X}$ & $\mathrm{X}$ & $\mathrm{X}$ & $\mathrm{X}$ & $\mathrm{X}$ & $\mathrm{X}$ & $\mathrm{X}$ & $\checkmark$ & $\mathrm{X}$ & $\mathrm{X}$ & $\mathrm{X}$ \\
\hline Percentage, \% & 66,67 & 66,67 & 66,67 & 66,67 & 66,67 & 66,67 & 66,67 & $66,67 \%$ & 100 & 66,67 & 66,67 & 66,67 \\
\hline Average & $69,44 \%$ & & & & & & & & & & & \\
\hline
\end{tabular}

Source; primary data processed (2018).

All successors' candidate gain development through education and knowledge transfer. Only a fraction of a successor has experience outside of the family company. It can be concluded that most or $69.44 \%$ keluaga founder or business leader to develop the candidate of successor.

In this study prospective successors are involved in activities (1) decision making process (2) giving responsibility and (3) building cooperation.

Table 3 - The involvement of potential successors in the family business

\begin{tabular}{|c|c|c|c|c|c|c|c|c|c|c|c|c|}
\hline \multirow[t]{2}{*}{ Involvement in Matter } & \multicolumn{12}{|c|}{ Successors Candidate } \\
\hline & 1 & 2 & 3 & 4 & 5 & 6 & 7 & 8 & 9 & 10 & 11 & 12 \\
\hline Decision-making process & $\checkmark$ & $\checkmark$ & $\checkmark$ & $\checkmark$ & $\checkmark$ & $\checkmark$ & $\checkmark$ & $\checkmark$ & $\checkmark$ & $\checkmark$ & $\checkmark$ & $\checkmark$ \\
\hline \multicolumn{13}{|c|}{ Giving responsibility for the company's operational activities } \\
\hline Purchase of grain & $\checkmark$ & $\checkmark$ & $\checkmark$ & $\checkmark$ & $\checkmark$ & $\checkmark$ & $\checkmark$ & $\checkmark$ & $\checkmark$ & $\checkmark$ & $\checkmark$ & $\checkmark$ \\
\hline The drying of grain & $\checkmark$ & $\checkmark$ & $\mathrm{X}$ & $\mathrm{X}$ & $\checkmark$ & $\checkmark$ & $\checkmark$ & $\checkmark$ & $\mathrm{X}$ & $\checkmark$ & $\checkmark$ & $\checkmark$ \\
\hline Operation of the machine & $\checkmark$ & $\checkmark$ & $\mathrm{X}$ & $\mathrm{X}$ & $\checkmark$ & $\checkmark$ & $\mathrm{X}$ & $\mathrm{X}$ & $\mathrm{X}$ & $\checkmark$ & $\mathrm{X}$ & $\checkmark$ \\
\hline Packaging & $\checkmark$ & $\checkmark$ & $\mathrm{X}$ & $\mathrm{X}$ & $\mathrm{X}$ & $\mathrm{X}$ & $\checkmark$ & $\checkmark$ & $\mathrm{X}$ & $\checkmark$ & $\checkmark$ & $\checkmark$ \\
\hline Marketing & $\checkmark$ & $\checkmark$ & $\checkmark$ & $\checkmark$ & $\checkmark$ & $\checkmark$ & $\checkmark$ & $\checkmark$ & $\checkmark$ & $\checkmark$ & $\checkmark$ & $\checkmark$ \\
\hline Administration & $\checkmark$ & $\checkmark$ & $\checkmark$ & $\checkmark$ & $\mathrm{X}$ & $\mathrm{X}$ & $\mathrm{X}$ & $\mathrm{X}$ & $\mathrm{X}$ & $\checkmark$ & $\checkmark$ & $\checkmark$ \\
\hline c. build partnership & $\checkmark$ & $\checkmark$ & $\checkmark$ & $\checkmark$ & $\checkmark$ & $\checkmark$ & $\checkmark$ & $\checkmark$ & $\mathrm{X}$ & $\checkmark$ & $\mathrm{X}$ & $\checkmark$ \\
\hline Percentage & 100 & 100 & 62,5 & 62,5 & 75 & 75 & 75 & 75 & 12,5 & 100 & 62,5 & 100 \\
\hline Average & $75 \%$ & & & & & & & & & & & \\
\hline
\end{tabular}

Source: primary data processed (2018). 
A total of $75 \%$ or most successor's candidate engaged in business activities, such as the decision-making process, giving them responsibility in the company's operations and build cooperation.

Collaboration built by prospective successors namely; (1) cooperation with raw material suppliers and (2) cooperation with permanent customers. Collaboration with raw material suppliers is usually carried out during each rice harvest season. This means that they make large-scale purchases to meet the supply of raw materials until the next rice harvest season. In an effort to collaborate with regular customers, prospective successors usually provide convenience in completing payment transactions and product delivery in a timely manner according to customer demand.

$$
\text { Successsion proccess }=\frac{\text { Stage } 1+\text { Stage } 2+\text { Stage } 3}{3}=78,90 \%
$$

So, the percentages obtained was $78.90 \%$, this results is $>50 \%$, indicate that the successor is ready to replace the founder or manager as a family business leader.

\section{CONCLUSION}

There are three stages of the succession process followed by the successor of the family business in the rice milling industry in Aceh Besar district, while those that can be concluded from these stages are; (1) At the stage of determining the criteria for candidate successors, almost all or $92.27 \%$ of candidates for successor have criteria acceptable, charismatic, energic, managing, achieving and networking; (2)At the stage of developing a successor, $69.44 \%$ or most of family business leaders develop a candidate of successor and (3) At the stage of involvement in the family business, $75 \%$ or most of prospective successors are involved in every business activity. So that the percentages of succession process are $78.90 \%$, this results $>50 \%$, indicate that the successor is ready to replace the founder or manager as a family business leader

This study is expected to contribute for development of knowledge about family business in Indonesia and to be references about family business in Indonesia which is very limited.

\section{REFERENCES}

1. Assanto, F. M. (2014). Perencanaan Suksesi Pada Perusahaan Keluarga Pt. Indoraya Sekaye Di Surabaya. Agora, 2(2), 807-817

2. Florentine, I. (2014). Persiapan Generasi Pendahulu Dan Kesiapan Generasi Penerus Pada Proses Suksesi Kepemimpinan Di PT IDR. Agora, 2(2), 1404-1410.

3. Foris, P. J. 2015. Analisis Strategi Pada Perusahaan Plastik Dengan Porter Five Forces. Agora, 3(1), 736-741.

4. Gordon, G., \& Nicholson, N. 2008. Family Wars: Classic Conflicts In Family Business And How To Deal With Them. Kogan Page Publishers.

5. Hartanto, F. M. 2009. Paradigma Baru Manajemen Indonesia: Menciptakan Nilai Dengan

6. Bertumpu Pada Kebajikan Dan Potensi Insani. PT Mizan Publika.

7. Pitoy, S. (2014). Perencanaan Suksesi pada PT. PQR Di Surabaya. Agora, 2(2), 11011104.

8. Price Waterhouse Coopers Survey. 2014. Survey Bisnis Keluarga 2014: Indonesia. Jakarta: Price Waterhouse Coopers.

9. Suharsaputra, uhar. 2012. Metode Penelitian Kuantitatif, Kualitatif dan Tindakan. PT. Refika Aditama; Bandung.

10. Sutedi, Adrian.2011. Good Corporate Governance. Jakarta, Sinar Grafika.

11. Susilo, NB. 2006. Seri Manajemen Bisnis Akhir Zaman Kepemimpinan Sulaiman Bagi Para Usahawan. Yogyakarta. Indonesia Cerdas. 
12. Soegoto, Eddy S.2009. Entrepreneurship Menjadi Pebisnis Ulung; Panduan Bagi Pengusaha, Calon Pengusaha, Mahasiswa Dan Kalangan Dunia Usaha Edisi Revisi. PT. Elex Media Komputindo (Kompas Gramedia). Jakarta.

13. Susanto, A. B. 2005. World Class Family Business. Mizan Pustaka.

14. Tjondrorahardja, Daud D. 2004. Family Business from ABC to MBA. Graha IImu. Yogyakarta.

15. Tjiang, C. G. H Dan Mustamu, Ronny H (2014). Studi Deskriptif Perencanaan Suksesi

16. Kepemimpinan Pada Perusahaan Keluarga Di Bidang Konstruksi Di Sidoarjo. Agora, 2(2), 1369-1379.

17. Tirdasari, N. L., \& Dhewanto, W. 2012. Family Business Succession In Indonesia: A Study of Hospitality Industry. Procedia-Social And Behavioral Sciences, 57, 69-74.

18. Wahjono, S. I. 2013. Penguatan Bisnis Keluarga Anggota Muhammadiyah Untuk Meningkatkan Bisnis Masyarakat Islam. Jurnal Salam, 15(2).

19. Wahjono, S. I. 2009. Suksesi Dalam Perusahaan Keluarga. Jurnal Balance, 3(1).

20. Wahjono, S. I. 2011. Suksesi Internal Bisnis Keluarga Untuk Penguatan Ekonomi Nasional Menghadapi Persaingan Bebas Afta-China. National Conference on Perkembangan Bisnis \& Industri Indonesia, Kesiapan dalam Menghadapi Persaingan Bebas AFTA-China, Jurusan IImu Ekonomi, FBE, Universitas Surabaya dan Forum Dosen Ekonomi ISEI Jawa Timur, 11 Juni 2011, ISBN no: 978-602-99352-0-2, pp: 16-35.

21. Zimmerer, Thomas W dan Scarborough,Norman M. 2008. Kewirausahaan dan manajemen usaha kecil edisi 5. Salemba 4. Jakarta.

22. Zubir, N. 2008. Famillionaire: Membangun Bisnis Keluarga Yang Solid Dari Generasi Ke Generasi. Jakarta: Penerbit Hikmah (PT Mizan Publika). 